\title{
IAMJ
}

INTERNATIONAL

AYURVEDIC

MEDICAL JOURNAL

\section{PHARMACOGNOSTICAL EVALUATION OF SHATAVARI (ASPARAGUS RACEMOSUS WILLD.) ROOT COLLECTED IN DIFFERENT SEASONS - A COMPARATIVE STUDY}

\author{
Kinjal Unadkat ${ }^{1 *}$, Muthiah Daniel ${ }^{2}$, Dilip K. Jani ${ }^{3}$ \\ 1*Assistant Professor, Department of Dravyaguna, Noble Ayurved College and Research Institute, Junagadh, \\ Gujarat, India \\ ${ }^{2}$ Dean and HOD, Department of Faculty of Science, Maharaja Sayajirao University, Vadodara, \\ Gujarat, India \\ ${ }^{3}$ Professor \& HOD, Upgraded Department of Dravyaguna, Government Ayurved College, Vadodara, \\ Gujarat, India
}

Corresponding Author: unadkatkinjal1@gmail.com

https://doi.org/10.46607/iamj0509092021

(Published Online: September 2021)

Open Access

(C) International Ayurvedic Medical Journal, India 2021

Article Received: 21/08//2021 - Peer Reviewed: 02/09/2021 - Accepted for Publication: 08/09/2021

\section{Check for updates}

\begin{abstract}
Background: In the current scenario, plant-based traditional medicines are providing a base for treating various diseases. It has been reported that $80 \%$ of the population of the world depends upon traditional medicine. It has been also shown that many factors like habitat, climate, temperature, season etc can affect the quality of medicinal plants. The study was conducted to explore such Ayurvedic documented literature with pharmacognostical study. Aim: To study macroscopic and microscopic characters of the drug samples collected in four different seasons according to Ayurveda classics. Materials \& Methods: In the present study, four samples of Asparagus racemosus were collected in four different seasons- Grishma, Pravrut, Sharad and Shishira Ritu (May, June, October, and January) based on Ayurveda classics for comparing the pharmacognostic characters so that they can be distinguished from each other. Results and Discussion: The influence of seasons on four different samples was ob-
\end{abstract}


served in terms of the sizes of roots, xylem vessels, phloem, raphide bundles of calcium oxalate etc. Conclusion: The seasons on the roots of Shatavari exhibited an effect in macroscopical and microscopical characters. Thus, it can be said that the season for collection of the drug has an important role to validate the factors that influence the potency of the drug.

Keywords: Ayurveda, Shatavari, Asparagus racemosus, Dravya Sangraha Kala, Pharmacognostical study

\section{INTRODUCTION}

India has the richest repository of traditional healthcare systems like Ayurveda, Unani, and Siddha with wide acceptance. There is a universal rise in the use of Ayurveda medicines since the Ayurveda systems of medicine is being largely plant-based and generally safe with a minimum side effect or no side effect. The increasing demand and multiple uses lead to substitution and adulteration. Pharmacognostical study is one of the solutions regarding the issues of substitutions and adulterations. Nature is an excellent source of drugs. The plant used in traditional medicine varies throughout the year in amount or quantity and the nature of active constituents has been reported different from season to season. For getting the highest quality, potentiality, and clinical efficacy of the drug, it should be collected during the appropriate season. Thus, it will be interesting to know in which season the part of the plant should be collected. In Ayurveda classics, there is a description regarding the collection of parts of the plants in a specific season (Table 1). With the help of pharmacognostical study, the variations like the morphological character of a drug, cell structure, tissue structure, specific features according to season can be differentiated. The purpose of collection in different seasons was to compare the pharmacognostic characters so that they can be distinguished from each other. The present work was a humble effort to observe the effect of seasonal variations of Shatavari roots pharmacognostically to validate the concept of "Dravyasamgraha Kala" which is one of the fundamental principles of Ayurveda.

\section{AIM AND OBJECTIVES}

1. To study organoleptic characters of the samples of roots of Asparagus racemosus in different seasons.
2. To study macroscopic characters of the samples in different seasons.

3. To study microscopic characters of the samples in different seasons.

4. To study powder microscopy of the samples in different seasons.

\section{MATERIALS AND METHODS}

In current research work, the samples of Asparagus racemosus were collected in different seasonsGrishma, Pravrut, Sharad and Shishira based on Ayurveda classics (Table 1). As per the reference in Sushruta Samhita, it is said that the drug should be used after one year ${ }^{6}$. So, the first sample was collected for the study after one year. The sample drug plant (Asparagus racemosus) was propagated in ten clay pots in May 2018. Then after one year, the first sample was collected in May 2019.

The fresh tuberous roots of Shatavari were collected and washed in the four seasons for study and root powders of four samples of Asparagus racemosus were also studied. The transverse and longitudinal sections were studied of the samples. The studies of all the samples were conducted at Dr Daniel's laboratory, Vadodara.

\section{PHARMACOGNOSTICAL STUDY}

\section{Organoleptic Study:}

The samples of Shatavari roots in different seasons were studied by sense organs which refer to shape, size, specific features, touch, odour, taste etc. (Table 2)

\section{Macroscopic Study}

Asparagus racemosus Willd is an excessively branched (Bahusuta) scandent spiny twining undershrub or occasionally climbing to great heights on tall trees. It has a short stout rootstock bearing numerous considerably long fusiform succulent tuberous roots. 
The roots are arising from the rootstock. The four samples of roots were found creamish white and their surfaces were found rough which showed wrinkles longitudinally after the roots were dried. When the roots were transversely cut, they showed a yellow peripheral strip, a silvery-white fleshy soft middle region that formed the bulk part of the root and a slightly hard narrow central woody core. It was found that the size of roots varied according to their seasonal collection. They were found about $33-79 \mathrm{~cm}$ long in different seasons. The sizes of the roots were: first sample- $33 \mathrm{~cm}$, second sample- $56 \mathrm{~cm}$, third sample$59 \mathrm{~cm}$ and fourth sample- $62 \mathrm{~cm}$ (Fig. 1).

\section{Microscopic study}

In the microscopic study, both transverse and longitudinal sections of the samples in different seasons were taken and powder microscopy was also done after proper mounting and staining with different reagents like safranin. Each common and distinguished character were noted down.

The common characteristics observed were cork, cortex, piliferous layer, xylem, phloem, pith, raphide bundles of calcium oxalate in transverse section (fig.2), while tracheids in longitudinal section (fig. 3) and cork cells, cortex, tracheids and parenchymatous cells in powder microscopy (fig.3).

There are some quantitative variations in the microscopic study of the samples. The xylem was found higher (30-35 xylem) and the metaxylem (2-3) were also present in the fourth sample. The raphide bundles of calcium oxalate (acicular crystals: 25-28) were also found higher in the fourth sample which was collected in Shishira Ritu (January 2020) with the reference of Raj nighantu, while xylem was observed less in the first and second sample collected in Grishma and Pravrit Ritu (fig.4) with the references of Charaka Samhita and Sushruta Samhita. The starch grains were not found in all the samples (Fig. 2).

\section{OBSERVATIONS \& RESULTS}

The samples of Shatavari roots were showed distinguished microscopic characters as collected in different seasons (Table 3 and Fig. 4).

\section{DISCUSSION AND CONCLUSION}

In the recent era, it is very difficult to get the proper drug. A pharmacognostical study is an important tool for authentication of the genuine drug. The plants are showed quantitative variations from season to season. The season for collection of the drug has an important role to validate the factors that influence the potency of the drug. With the help of pharmacognostical study, it is possible to distinguish the variations of different samples collected in different seasons of the same plant. It was studied and reported here. The morphological features were found more similar except for the sizes of the roots of the samples. But the microscopic study was showed variations among the four different samples. The xylem and metaxylem which transport water from roots to stems, leaves and provides nutrition to the whole plant were found higher in Shishira rutu (30-35 xylem and metaxylem 2-3 in January 2020). The raphide bundles of calcium oxalate (acicular crystals) have a central role in a variety of functions including tissue calcium regulation, protection from herbivory, metal detoxification, supporting ascorbic acid as the primary precursor to oxalate biosynthesis. The raphide bundles were found higher in Shishira Rutu (25-28 in January) while the xylem and the raphide bundles of calcium oxalate (acicular crystals) were observed less in the first and second samples (Grishma and Pravrut rutu). Thus, the fourth sample is observed to be the best. The theory put on by Raj nighantu seems to be justified in the current study. It shows seasonal variations of plants and the importance of the study. With the results, it can be said that the roots of the plant should be collected in Shishira rutu. In the Classics, it is mentioned that the root of Shatavari should be used in Aardravastha (wet state) and mentioned that it should be used in dry powder form in formulations. Powder microscopy of the samples of Shatavari roots was also evaluated. The knowledge of plant-based traditional medicines is always required for Ayurveda physicians. For that, it is important to select good quality medicine, seasonal collection and to prevent substitution and adulteration. 


\section{REFERENCES}

1. Agnivesha, Charaka Samhita of Acharya Charaka, Dridhabala, edited by Prof. Rajeshwara Datta Shastri, Prof. Yadunandana Upadhyaya, Prof. Ganga Sahaya Pandey, with Vidyotini Hindi commentary by Pandita Kashinatha Shastri and Dr Gorakhanatha Chaturvedi Kalpa Sthana. Ka.1, Ver.10. Reprint, Varanasi: Chaukhambha Bharti Academy; 2016. p.894.

2. Vriddha Sushruta, Sushruta Samhita of Acharya Sushruta, Nagarjuna, edited with Ayurveda Tattava Sandipika Hindi commentary by Kaviraj Ambikadatta Shastri, forwarded by Dr Pranajivana Mehta. Sutra Sthana. Su.37, Ver.6. Reprint, Varanasi: Chaukhambha Sanskrit Sansthan; 2014. p.180.

3. Sharangadhara, Sharangadhara Samhita, with Dipika Hindi commentary by Dr. Brahmanand Tripathi. Pur- va Khanda. Pu.1, Ver. 67. Reprint, Varanasi: Chaukhambha Orientalia; 2015. p.15.

4. Bhavamishra, Bhavaprakasha Samhita, with Vidyotini Hindi commentary by Shri Brahmashankara Mishra and Shri Rupalalaji Vaishya. Purva Khanda. Pu.6, Ver.91-97. 12 $2^{\text {th }}$ edition, Varanasi: Chaukhambha Sanskrit Bhavana; 2016. p.181-182.

5. Narahari Pandit, Raj nighantu, edited by Dr. Indradeva Tripathi, with Dravyagunaprakashika Hindi commentary. Dharanyadi Varga, Ver.57. Reprint, Varanasi: Chaukhambha Krushnadas Academy; 2010. p.26.

6. Vriddha Sushruta, Sushruta Samhita of Acharya Sushruta, Nagarjuna, edited with Ayurveda Tattava Sandipika Hindi commentary by Kaviraj Ambikadatta Shastri, forwarded by Dr Pranajivana Mehta. Sutra Sthana. Su.37, Ver.10, Reprint, Varanasi: Chaukhambha Sanskrit Sansthan; 2014. p.181.

Table 1: The description of a collection of drug samples in different seasons according to classics:

\begin{tabular}{|l|l|l|}
\hline Sr. No. & Sample and Season & Reference \\
\hline 1. & $1^{\text {st }}$ sample- Grishma (May 2019) & Charaka Samhita $^{1}$ \\
\hline 2. & $2^{\text {nd }}$ sample- Pravrut (June 2019) & Sushruta Samhita $^{2}$ \\
\hline 3. & $3^{\text {rd }}$ sample- Sharad (October 2019) & Sharangadhara samhita $^{3}$ \& Bhavaprakasha samhita $^{4}$ \\
\hline 4. & $4^{\text {th }}$ sample- Shishira (January 2020) & Raj Nighantu $^{5}$ \\
\hline
\end{tabular}

Table 2: Organoleptic characters of four samples of Shatavari root:

\begin{tabular}{|l|l|l|l|l|l|}
\hline No. & Characters & $\begin{array}{l}\mathbf{1}^{\text {st }} \text { sample } \\
(\text { Grishma-May })\end{array}$ & $\begin{array}{l}\mathbf{2}^{\text {nd }} \text { sample (Pravrut- } \\
\text { June })\end{array}$ & $\begin{array}{l}\mathbf{3}^{\text {rd }} \text { sample } \\
\text { (Sharad-October })\end{array}$ & $\begin{array}{l}\mathbf{4}^{\text {th }} \text { sample } \\
(\text { Shishira- January) }\end{array}$ \\
\hline 1. & Shape & Tuberous & Tuberous & Tuberous & Tuberous \\
\hline 2. & Surface & Rough & Rough & Rough & Rough \\
\hline 4. & Odour & Pleasant & Pleasant & Pleasant & Pleasant \\
\hline 5. & Taste & Bitter & Bitter & Slightly bitter & Sweetish Bitter \\
\hline 6. & Colour & Creamish white & Creamish white & Creamish white & Creamish white \\
\hline
\end{tabular}

Table 3: Comparative study of the samples of Shatavari root which are collected in different seasons is as follows:

\begin{tabular}{|l|l|l|l|l|l|}
\hline $\begin{array}{l}\text { Sr. } \\
\text { No. }\end{array}$ & Character & $\begin{array}{l}1^{\text {st }} \text { sample } \\
(\text { Grishma })\end{array}$ & $\begin{array}{l}2^{\text {nd }} \text { sam- } \\
\text { ple } \\
(\text { Pravrut })\end{array}$ & $\begin{array}{l}3^{\text {rd }} \\
\text { ple } \\
\text { (Sham- }\end{array}$ & $\begin{array}{l}4^{\text {th }} \text { sample } \\
\text { (Shishira) }\end{array}$ \\
\hline 1. & Xylem & $\begin{array}{l}8-10 \quad \text { xy- } \\
\text { lem }\end{array}$ & $10-12$ & $18-20$ & $\begin{array}{l}30-35 \text { xylem and 2-3 meta- } \\
\text { xylem }\end{array}$ \\
\hline 2. & $\begin{array}{l}\text { Raphide bundles of calcium oxalate (Acicular } \\
\text { crystal) }\end{array}$ & $5-6$ & $01-02$ & $20-25$ & $28-30$ \\
\hline 3. & Tracheids & Present & Present & Present & Present \\
\hline 4. & Parenchyma cells & Present & Present & Present & Present \\
\hline 5. & Pith & Present & Present & Present & Present \\
\hline
\end{tabular}


Figure 1: External morphology of roots of Asparagus racemosus collected in different seasons:

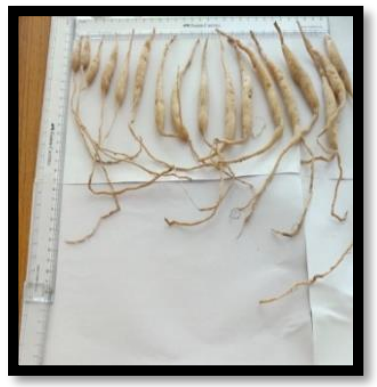

(A)

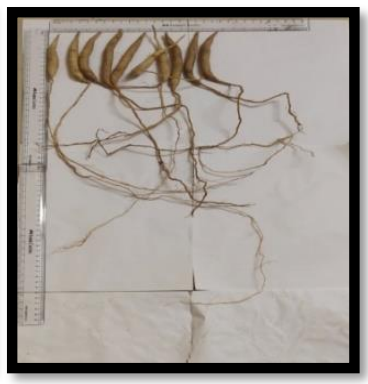

(B)

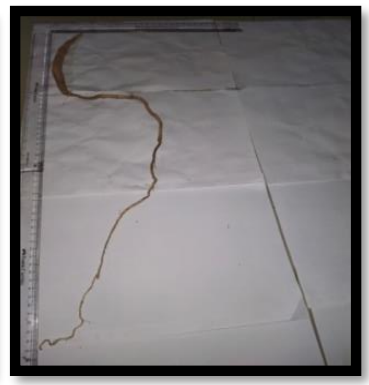

(C)

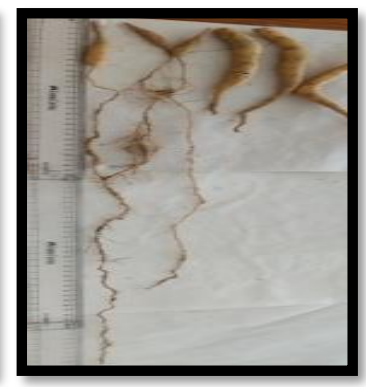

(D)

Figure 1: (A) - $1^{\text {st }}$ sample (May, 2019); (B) - $2^{\text {nd }}$ sample (June, 2019); (C) - $3^{\text {rd }}$ sample (October, 2019;) (D) $4^{\text {th }}$ sample (January, 2020)

Figure 2: The common microscopic characters in transverse section in different seasons

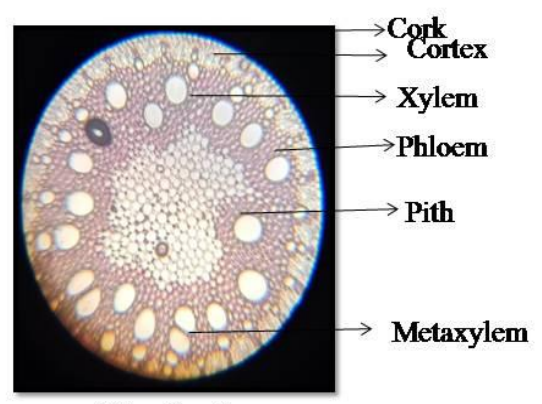

T.S. of root

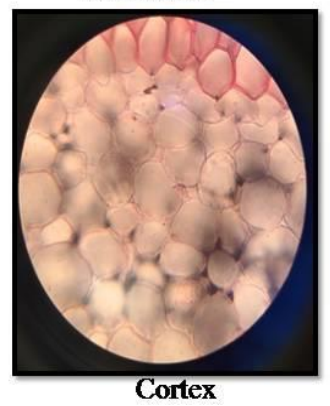

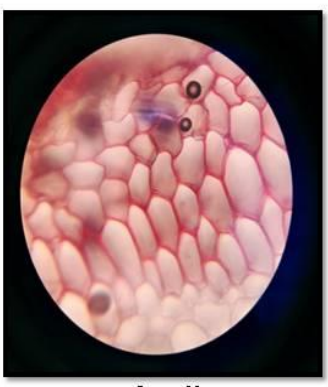

Cork cells

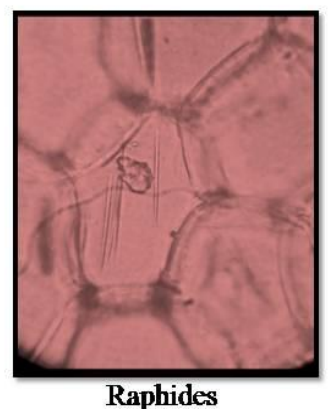

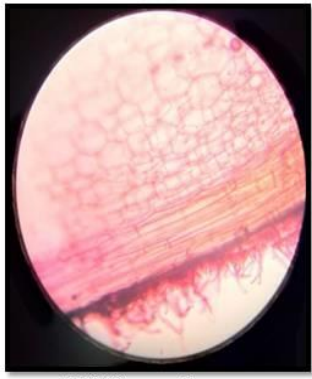

Piliferous layer

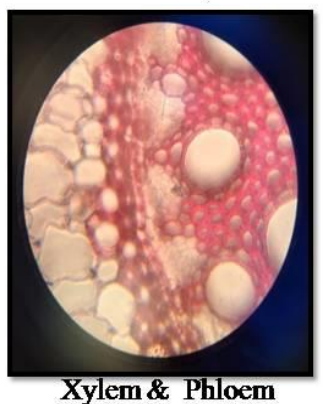


Figure 3: The common microscopic characters in longitudinal section and powder microscopy in different seasons
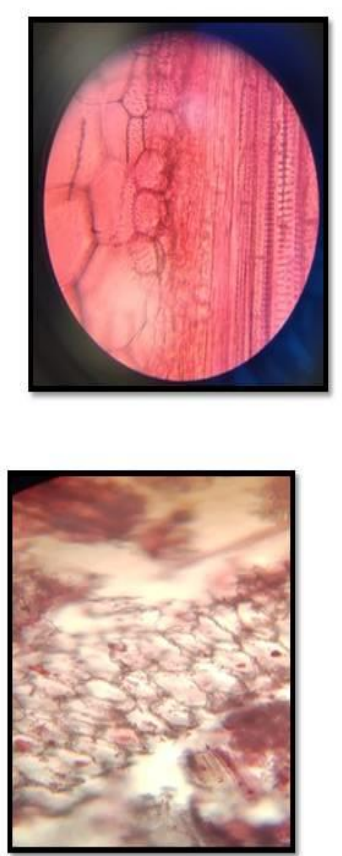

Cork cells in powder microscopy
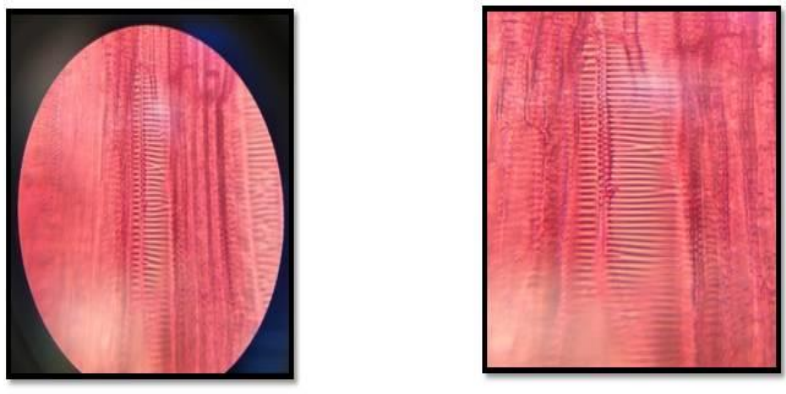

Tracheids in L.S. of root

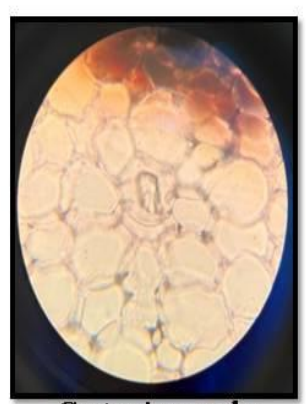

Cortex in powder microscopy

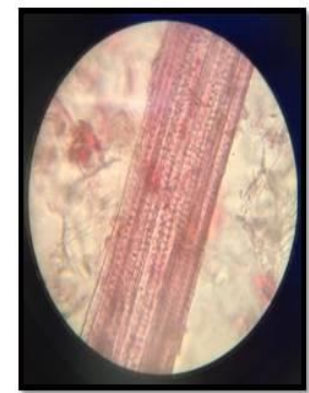

Tracheids in powder microscopy

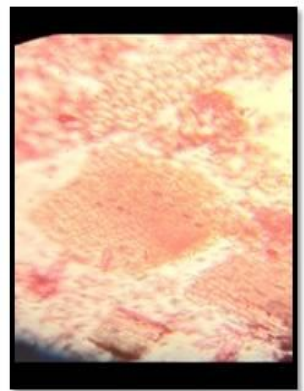

Parenchyma cells in powder microscopy

Figure 4: The distinguished microscopic characters in different seasons:

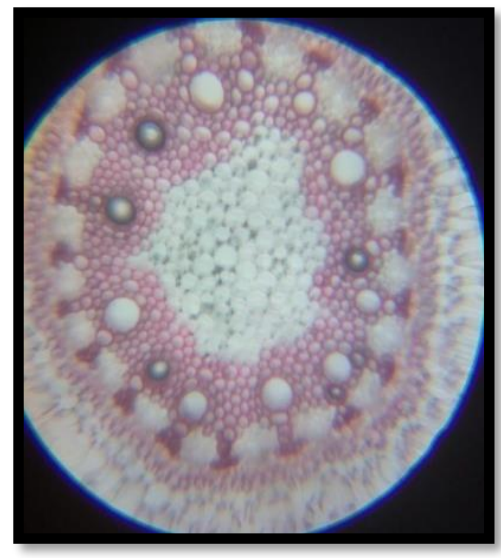

$1^{\text {st }}$ sample: Xylem: $8-10$

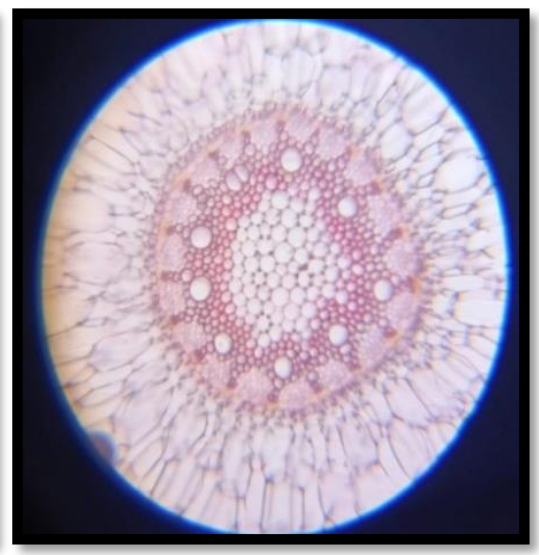

$2^{\text {nd }}$ sample: Xylem: 10-12

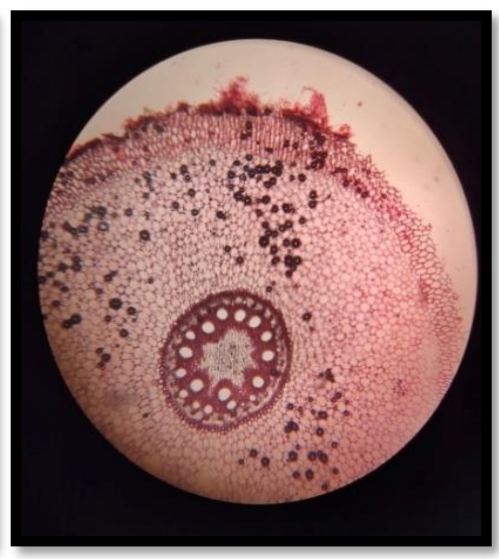

$3^{\text {rd }}$ sample: Xylem: $18-20$ 

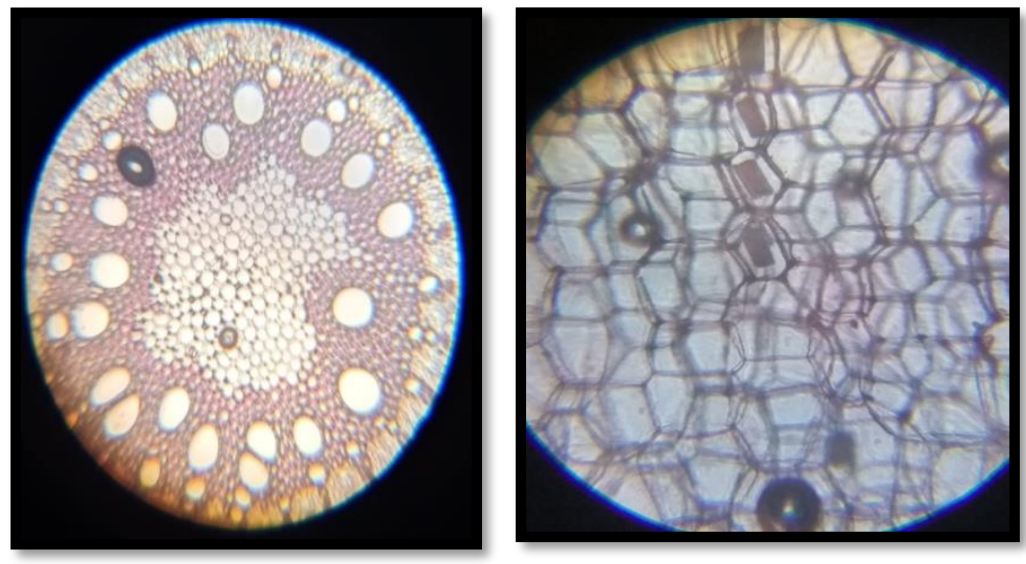

$4^{\text {th }}$ sample: Xylem: $30-35 \& 1^{\text {st }}$ sample: Raphides: 5-6 metaxylem: 2-3

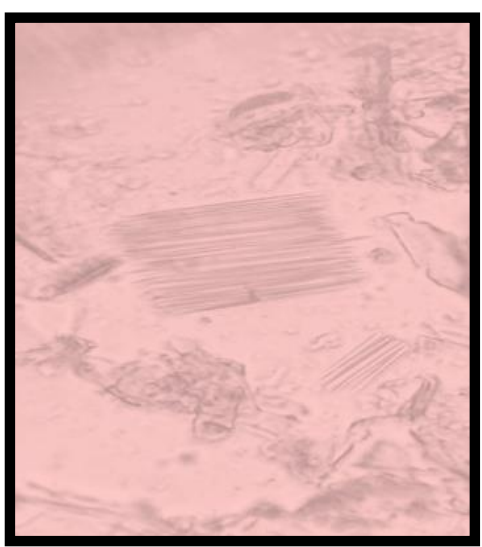

$2^{\text {nd }}$ sample: Raphides: $1-2$

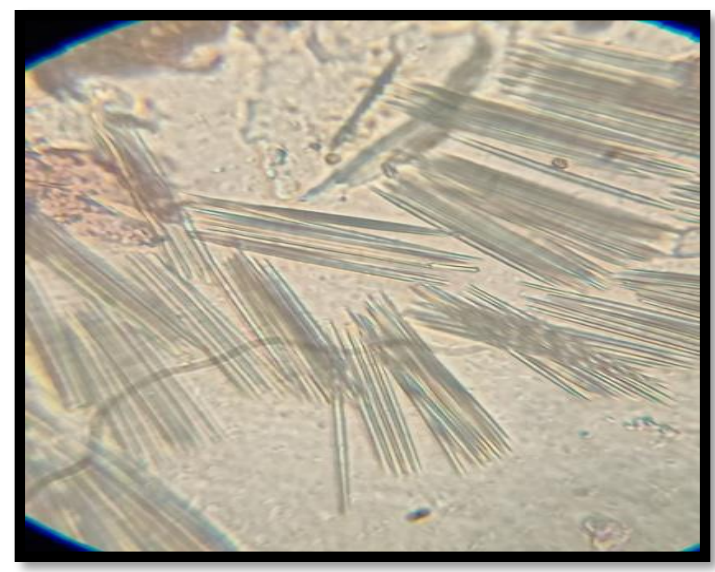

$4^{\text {th }}$ sample: Raphides: $28-30$

\section{Source of Support: Nil \\ Conflict of Interest: None Declared}

How to cite this URL: Kinjal Unadkat et al: Pharmacognostical Evaluation Of Shatavari (Asparagus Racemosus Willd.) Root Collected In Different Seasons - $\mathcal{A}$ Compara-tive Study. International Ayurvedic Medical Journal \{online\} 2021 \{cited September 2021\} Available from: http://www.iamj.in/posts/images/upload/1951_1957.pdf 